problemy formuvannia psykholoho-vykonavskoi maisternosti $\mathrm{v}$ konteksti kompensatornykh mozhlyvostei osobystosti [The problem of the formation of psycho-performing skill in the context of the compensatory capabilities of the individual]. Materialy mizhnarodnoi naukovoi konferentsii "Mystetska osvita: tradytsii inovatsii" Proceedings of the International Scientific Conference of "Art education: traditions of innovation". (pp. 146 - 148). Melitopol. [in Ukrainian].

5. Cherniak, Ye.B. (2016). Metodychni aspekty formuvannia profesiino-vykonavskykh kompetentsii muzykantiv z riznymy indyvidualnopsykholohichnymy osoblyvostiamy [Methodical aspects of the formation of professional-performing competences of musicians with different individual and psychological peculiarities]. Pedagogical Education: Theory and Practice. Collection of scientific works. Kamenetz-Podolsk National University named after Ivan Ogienko. KamenetzPodolsk, 20(1 - 2016). pp. 163 - 168. [in Ukrainian].

6. Cherniak, Ye.B. \& Yorkina, N.V. (2018). Formuvannia hendernoi kompetentnosti studentiv u protsesi yikh pidhotovky do umov vykonavskoi diialnosti [Formation of gender competence of students in the process of their preparation to the conditions of performance]. Alfred Nobel University Bulletin. Series: Pedagogy and Psychology. Dnepr, 2(16). pp. 102 - 109. [in Ukrainian].

Стаття надійшла до редакції 19.03.2019

УДК [378.015.3:005.32]:811.11’27

DOI:

Олена Малінка, кандидат педагогічних наук, старший викладач кафедри методики навчання іноземних мов Вінницького державного педагогічного університету імені М. Коцююбинського

\title{
КОМУНІКАТИВНА СПРЯМОВАНІСТЬ НАВЧАЛЬНОГО ПРОЦЕСУ ЯК НЕОБХІДНА ПЕРЕДУМОВА РОЗВИТКУ У СТУДЕНТІВ МОТИВАЦІЇ ДО ВИВЧЕННЯ ІНОЗЕМНОЇ МОВИ
}

У статті обтрунтовано необхідність організації процесу навчання студентів іноземної мови як процесу, спрямованого на розвиток їхніх комунікативних умінь та навичок. Розкрито зв 'язок між комунікативною спрямованістю навчання та розвитком мотивації до вивчення даної дисципліни; з'ясовано, що саме комунікативно-пізнавальна потреба є “пусковим механізмом” мовленнєвої діяльності, і обтрунтовано важливість створення мовленнсвих ситуацій в процесі навчання іноземної мови. На основі аналізу теоретичних праць вітчизняних та зарубіжних вчених визначено сутність комунікативного підходу, його основні принципи, та розглянуто методи, щуо використовуються в межах даного підходу.

Ключові слова: комунікативна спрямованість; комунікативний підхід; мотивачія; вивчення іноземних мов; мовленнєва діяльність; мовленнєва ситуачія.

Лim. 11.

Olena Malinka, Ph.D.(Pedagogy), Senior Lecturer of the Foreign Languages Teaching Methodology Department Vinnytsya Mykhaylo Kotsyubynskiy State Pedagogical University

\section{COMMUNICATIVE ORIENTATION OF EDUCATIONAL PROCESS AS A NECESSARY PREREQUISITE FOR DEVELOPMENT OF STUDENTS' FOREIGN LANGUAGES LEARNING MOTIVATION}

The necessity of organizing the process of teaching foreign languages to students as the process which is oriented towards their communicative skills and knowledge is substantiated in the article. The connection between communicative orientation of the educational process and development of foreign language learning motivation is highlighted. It is determined that a communicative and cognitive need is a "trigger" of speech activity, but its realization can be fulfilled only provided that there is a speech situation. Thus, the importance of creating speech situations in the process of foreign language learning is reasoned in the article as well. Speech situations can be different by the level of complexity: from reading and listening comprehension of advertisements, wording of simple requests and short answers to independent statements about works of arts etc. On the basis of the analysis of theoretical works of domestic and foreign scientists, the essence of the communicative approach, its main principles, and methods that are used within the framework of this approach are considered. According to the communicative approach the educational process serves as a model of natural communication process. Such organization of the 


\section{КОМУНІКАТИВНАСПРЯМОВАНІСТЬ НАВЧАЛЬНОГОПРОЦЕСУ ЯК НЕОБХІДНАПЕРЕДУМОВА РОЗВИТКУ У СТУДЕНТІВ МОТИВАЦІЇ ДО ВИВЧЕННЯІНОЗЕМНОӤ МОВИ}

learning process involves modeling the following fundamentally important communication parameters: the personal character of the communicative activity of the communication process; relationships and interaction of communication partners; situation as a form of functioning of the society; content basis of communication process etc. In the framework of this approach students learn communication in the process of communication itself. Its most important characteristic is the use of authentic materials that are really used by native speakers. The importance of the communicative approach is due to the fact that it actively contributes to the formation of the individual, since learning/teaching is carried out by discussing actual problems with the consideration of interests, outlook of students; communication conditions, close to the conditions of a natural linguistic environment are created at foreign language lessons that positively affects the development of internal communication motives.

Keywords: communicative orientation; communicative approach; motivation; foreign languages learning; speech activity; speech situation.

П остановка проблеми. Навчання студентів іноземної мови як засобу комунікації в контексті їньої майбутньої професійної діяльності має бути пріоритетним завданням викладачів вищої школи. На жаль, багатьма 3 них ігнорується важливість комунікативної спрямованості навчального процесу при викладанні іноземної мови, що негативно впливає на розвиток мотивації студентів до вивчення іноземної мови загалом, а також мотивації їхньої мовленнєвої діяльності зокрема.

Аналіз основних досліджень та публікацій. Теоретико-методологічною основою комунікативноорієнтованого підходу до вивчення іноземних мов $\epsilon$ праці багатьох зарубіжних та вітчизняних вчених, зокрема: О. Вовк, І. Зимньої, Н. Гез, У. Литлвуда, Ю. Пассова, Г.Піфо, О. Тарнопольського, Г. Уідоусана та ін. Проблема формування та розвитку у студентів мотивації мовленнєвої діяльності зокрема та мотивації до вивчення іноземної мови загалом висвітлюється в дослідженнях Б. Бєляєвої, А. Маркової, Ю. Маслової, Е. Непомнящої, Н.М. Симонової та ін. Питання зв'язку між вмотивованим $\mathrm{i}$, як наслідок, успішним вивченням студентами іноземної мови та комунікативною спрямованістю даного процесу залишається досить актуальним і потребує подальшого розгляду.

Метою статті $є$ обгрунтувати важливість комунікативної спрямованості процесу навчання студентів іноземної мови для розвитку у них мотивації до вивчення даної дисципліни i, як наслідок, для успішного оволодіння нею.

Викладення основного матеріалу. Оволодіння іноземною мовою вимагає щоденної, систематичної, і що дуже важливо, вмотивованої роботи. Студент повинен мати чітко поставлену мету вивчення цієї навчальної дисципліни, дуже добре усвідомлювати необхідність знання іноземної мови для майбутньої професійної діяльності. Хоча, як застерігають деякі вчені, зокрема Ю. Пассов, усвідомлення цілей вивчення іноземних мов не завжди є достатньо потужним мотивуючим засобом і не завжди здатне підтримувати пізнавальну активність студентів на належному рівні. Учений визначає два види спонукань, що мотивують процес навчання іноземним мовам. На його думку, це потреби, що випливають 3 психологічної моделі особистості (цілі, перспективи тощо), та пізнавальні інтереси, що витікають з внутрішньої моделі навчальної діяльності. Ще одним специфічним для навчання іноземних мов видом спонукань $€$, згідно 3 думкою вченого, функціонування соціальної мотивації, що базується на потребі спілкування [9, 198]. І.Зимня також серед умов, за яких $є$ можливим розвиток належної мотивації оволодіння іноземними мовами, називає формування комунікативнопізнавальної потреби, тобто потреби в спілкуванні, яке є можливим саме завдяки мові, оскільки вона $\epsilon$ засобом спілкування. Задоволення комунікативно-пізнавальної потреби відбувається завдяки реалізації комунікативного підходу в навчанні іноземних мов. Сугність даного підходу полягає в тому, що навчальний процес виступає моделлю процесу природного спілкування. Організація процесу навчання в якості такої моделі передбачає моделювання наступних принципово важливих параметрів спілкування: особистісний характер комунікативної діяльності процесу спілкування; взаємовідносини і взаємодія партнерів спілкування; ситуації як форма функціонування суспільства; змістова основа процесу спілкування; система мовленнєвих засобів; евристичність [8].

Важливість комунікативного підходу обумовлена тим, що він активно сприяе формуванню особистості, оскільки навчання відбувається шляхом обговорення актуальних проблем з урахуванням інтересів, світогляду тих, хто навчається, на заняттях створюються умови спілкування, наближені до умов природного мовного середовища, що позитивно впливає на розвиток внутрішніх мотивів спілкування. Чим менш навчальною буде діяльність, чим більш наближеною до умов реальної дійсності, тим вищим буде рівень мотивації. Перетворюючи навчальну задачу на задачу спілкування, яка $\epsilon$ особистісно значущою для студента, викладач 


\section{КОМУНІКАТИВНАСПРЯМОВАНІСТЬ НАВЧАЛЬНОГОПРОЦЕСУ ЯК НЕОБХІДНА ПЕРЕДУМОВА РОЗВИТКУ У СТУДЕНТІВ МОТИВАЦЇ̈ ДО ВИВЧЕННЯ ІНОЗЕМНОЇ МОВИ}

створює умови для зростання мотивації до оволодіння мовою.

На думку Ю. Пассова, комунікативний підхід орієнтований на організацію процесунавчання, що $\epsilon$ адекватним процесу реального спілкування завдяки моделюванню таких основних закономірностей мовленнєвого спілкування: 1) діяльнісний характер мовленнєвого спілкування, що втілюється в комунікативній поведінці викладача як учасника процесу спілкування та навчання, і в комунікативно вмотивованій, активній поведінці студента як суб' єкта спілкування та навчання; 2) предметність процесу комунікації, що має бути змодельована обмеженим, але точно визначеним набором предметів обговорення (тем, проблем, подій і т. ін.); 3) ситуації спілкування, що моделюються, як найтиповіші варіанти стосунків студентів між собою; 4) мовленнєві засоби, які забезпечують процес спілкування та навчання за даних ситуацій [9].

Відповідно вчений висуває наступні принципи комунікативного підходу: 1) мовленнєва спрямованість навчального процесу, яка полягає не стільки в тому, що ставиться мовленнєва практична мета (це є характерним для багатьох інших підходів), скільки в тому, що шляхом до цієї мети є саме практичне користування іноземною мовою; 2) індивідуалізація при керівній ролі іiі особистісного аспекту як головного засобу створення мотивації та активності студентів 3 урахуванням їхнього життєвого досвіду, контексту діяльності, сфери інтересів, емоційної сфери і статусу конкретної особистості в колективі; 3 ) функціональність, яка забезпечує відбір іншомовного матеріалу як такого, що $\epsilon$ адекватним процесу комунікації; 4) ситуативність, що розглядається як засіб мовленнєвої стимуляції і як умова розвитку мовленнєвих навичок; при цьому під “ситуацією” розуміють систему взаємовідносин співрозмовників, яка відбивається в їхній свідомості; 5) новизна, що проявляється в постійній зміні предмета розмови, обставин, завдань тощо [9].

Навчання мовленню за комунікативною методикою передбачає широке використання різноманітних опор: змістових та смислових, словесних і зображувальних (текст, мікротекст, логіко-синтаксична схема тощо). Також використовуються мовні ігри, що дають змогу спілкуватися в різних соціальних контекстах та в різних ролях.

В межах комунікативного підходу з кінця ХХ століття досить активно використовуються методи, що об'єднують у собі комунікативні та

пізнавальні (академічні) цілі. Серед основних характеристик цих методів визначають: рух від цілого до окремого; орієнтація занять на студента; цілеспрямованість, змістовність та спрямованість занять на досягнення соціальної взаємодії за наявності віри викладача в успіх своїх студентів, інтеграція мови та засвоєння іï за допомогою знань з інших галузей наук.

Отже, комунікативне навчання іноземних мов - це навчання спілкуванню, основна мета якого, як стверджує Л. Базель, - досягнення студентами здатності ефективно і відповідно до ситуації використовувати лінгвістичну систему. Таку здатність дослідниця називає “мовною компетенцією”. У дослідженні Г. Китайгородської зустрічаємо термін “комунікативна компетенція”, під яким вчена розуміє здатність брати участь у реальному спілкуванні іноземною мовою [4]. На думку В. Булгакової, комунікативна компетенція $\epsilon$ здатністю людини до спілкування в одному або деяких видах мовленнєвої діяльності, яка являє собою набуту у процесі природної комунікації або спеціально організованого навчання особливу якість мовної особистості [1]. Поняття “комунікативна компетенція" $є$ дещо вужчим за поняття “комунікативна компетентність” і ототожнювати їх, на думку Г. Вороніної, В. Краєвського, Н. Кузьміної та ін., не слід. Компетенція є колом питань, стосовно яких особистість добре обізнана, і має досвід. Компетентність у певній сфері є поєднанням відповідних знань і здібностей, що дозволяють обгрунтовано судити про цю сферу та ефективно діяти в ній. Комунікативна компетентність - це узагальнена комунікативна властивість особистості, що включає розвинуті комунікативні здібності, сформовані уміння і навички міжособистісного спілкування, знання про основні його закономірності та правила [6]. ЗаВ. Булгаковою, комунікативна компетентність $є$ показником поінформованості суб' єкта спілкування у сфері комунікації, задовільного оволодіння певними правилами, нормами поведінки, спілкування [1]. Розмежовуючи поняття “компетенція" i “компетентність”, ми поділяємо думку Е. Зеєра та А. Хуторського стосовно того, що компетенція - це набір здібностей, знань, умінь та навичок у відповідній галузі, тобто певний потенціал особистості, а компетентність - рівень володіння цим потенціалом, характеристика самої особистості, що показує рівень володіння компетенція ми [2].

За комунікативного підходу студенти навчаються комунікації у процесі самої комунікації. Його найважливішою характеристикою $є$ 


\section{КОМУНІКАТИВНАСПРЯМОВАНІСТЬ НАВЧАЛЬНОГОПРОЦЕСУ ЯК НЕОБХДНА ПЕРЕДУМОВА РОЗВИТКУ У СТУДЕНТІВ МОТИВАЦІЇ ДО ВИВЧЕННЯ ІНОЗЕМНОӤ МОВИ}

використання автентичних матеріалів, тобто таких, що дійсно використовуються носіями мови. В процесі мовленнєвої взаємодії студенти співпрацюють не тільки один з одним (в парах, тріадах, невеликих групах, 3 усією групою), а і 3 викладачем. 3 самого початку вони оволодівають усіма чотирма видами мовленнєвої діяльності (говоріння, читання, письмо, аудіювання) на понадфразовому і текстовому рівнях, використання рідної мови є обмеженим. Водночас при оцінюванні враховується не тільки правильність, але й швидкість усного мовлення та читання.

Отже, пріоритетним завданням при навчанні студентів іноземних мов має бути формування саме іншомовної комунікативної компетентності, що здійснюється в межах компетентнісного підходу. Т. Сорочан визначає даний підхід як переорієнтацію 3 процесу на результат у діяльнісному вимірі [11]. На думку О. Пометун, компетентнісний підхід передбачає спрямованість освітнього процесу на формування і розвиток ключових та предметних компетентностей особистості. Якщо сфера життя, в якій особистість відчуває себе компетентною, $\epsilon$ досить широкою, то, як стверджує вчений, мова йде про ключові компетентності. Компетентність, що розповсюджується на вужчу сферу, у рамках певної наукової дисципліни (у нашому випадку іноземної мови) $\epsilon$ предметною [10].

На основі методологічного принципу єдності свідомості та діяльності об' єктом навчання, згідно з О. Леонтьєвим, є мовленнєва діяльність, яка визначається автором як процес реалізації комунікативно-пізнавальної потреби в передачі думки та отриманні інформації, заповненні інформаційного вакууму, вербальному осмисленні дійсності. Виходячи з визнання мовленнєвої діяльності об'єктом навчання, під час розробки стратегії та тактики навчання слід враховувати наступні характеристики діяльності взагалі: вона породжується певним комплексом причин i здійснюється за певними законами; в ній неминуче знаходить відображення особистість суб'єкта діяльності; діяльність обумовлює становлення і розвиток властивостей і якостей особистості [5].

Значний інтерес для нас становить запропонована I. Зимньою трирівнева структура мовленнєвої діяльності: перший рівень мовленнєвого процесу - спонукальний (представлений потребою, мотивом, метою); другий - формувальний (пов'язаний з мисленням, оформленням думок у внутрішньому мовленні та певним індивідуальним змістом як результатом); третій - реалізуючий (передбачає оформлення індивідуального змісту узовнішньому мовленні i, як результат, певне соціальне значення) [3, 60 - 65].

Спонукальний або мотиваційно-спонукальний рівень являє для нас найбільший інтерес, оскільки саме він безпосередньо пов' язаний з проблемою, що розглядається в даній статті. За своєю сутністю цей рівень $\epsilon$ потребнісно-мотиваційноцільовим, а за своєю функцією - спонукальним, що $є$ досить важливою деталлю, оскільки саме завдяки їй постає питання про необхідність створення в процесі навчання ситуацій, які б сприяли появі і розвитку комунікативнопізнавальної потреби, тобто потреби у здійсненні мовленнєвої діяльності, що одностайно визнана психологами однією з основних соціогенних потреб людини. Вона $\epsilon$ найбільш значущою у навчанні усного мовлення і в мотиваційній сфері студентів займає одне 3 провідних місць, поряд 3 творчою, та 3 потребою в досягненнях. Як стверджує О.Леонтьєв, створення найсприятливіших умов для розвитку мотивації та творчого характеру навчальної діяльності можливе саме у процесі спілкування. Отже, навчальну діяльність в процесі вивчення іноземних мов доцільно будувати як модель процесу спілкування і саме такої діяльності слід навчати студентів, а через оволодіння ㄲï способами та засобами формувати і того, хто навчається [5].

Оскільки головною метою вивчення студентами іноземної мови $€$ навчання їх спілкуванню, одним 3 найважливіших концептуальних положень, яких слід дотримуватися в процесі організації навчального процесу, є формування в них мотивації мовленнєвої діяльності, в ході якої виробляються комунікативні навички та усуваються психологічні бар'єри, що перешкоджають навчальному процесу.

Отже, комунікативно-пізнавальна потреба виступає в якості “пускового механізму” або “енергетичного джерела" мовленнєвої діяльності. Проте реалізація ііі можлива лише, коли має місце поєднання iï з умовами, що здатні задовольнити цю потребу. Однією $з$ таких умов у процесі навчання іноземних мов $є$ наявність мовленнєвої ситуації. За такого поєднання в психіці людини виникає певний динамічний стан, що знаходить вираження у психологічній готовності до здійснення актів поведінки у відповідному напрямку. Орієнтовна діяльність, що здійснюється у процесі вирішення мовленнєвої ситуації і передбачає опору на іноземне мовлення, є основною метою практичної підготовки студентів 3 іноземної мови. Ця діяльність охоплює сприйняття ситуації, усвідомлення проблеми спілкування, вибір комунікативної мети, пошук 


\section{КОМУНІКАТИВНАСПРЯМОВАНІСТЬ НАВЧАЛЬНОГОПРОЦЕСУ ЯК НЕОБХІДНА ПЕРЕДУМОВА РОЗВИТКУ У СТУДЕНТІВ МОТИВАЦЇ̈ДО ВИВЧЕННЯІНОЗЕМНОӤ МОВИ}

вирішення проблеми в спілкуванні, досягнення комунікативної мети і результату. Останній $є$ головним показником готовності студентів до практичної професійної діяльності засобами іноземної мови.

Мовленнєві ситуації бувають досить різноманітними за рівнем складності: від читання і сприйняття на слух оголошень, реклам, формулювання нескладних прохань та коротких відповідей до написання анотацій за статтею, самостійних висловлювань про витвори мистецтва, початкового філологічного аналізу. Ці цілі можуть реалізовуватися у різних формах практичної діяльності, а саме у міжособистісному спілкуванні, у діяльності за інтересами, а згодом і упрофесійній діяльності $[7,59]$.

Висновки. Отже, початковим механізмом комунікативної діяльності $\epsilon$ виникнення потреби у спілкуванні, яке, в свою чергу, вже є поштовхом до виникнення відповідного мотиву, приводить в дію мотивацію. Як стверджують психологи, механізм мотивації породження висловлювання $\epsilon$ індивідуальним та безпосередньо некерованим, але піддається опосередкованому регулюванню. Це свідчить про те, що викладач може певним чином впливати на мотиваційну сферу студентів. Тому навчання іншомовного спілкування має бути спрямоване на вироблення у студентів мотивації мовленнєвої діяльності та формування мовленнєвих навичок в процесі навчання; для цього необхідно створювати комунікативнорефлексивне середовище, що передбачає розв'язання комунікативних задач. Оскільки головною метою вивчення іноземної мови в закладах вищої освіти є розвиток умінь студентів використовувати мову як засіб спілкування у сфері майбутньої професійної діяльності, то навчальний процес має бути спрямований саме на реалізацію вказаної мети, що можливо за умови врахування принципів комунікативного підходу в навчанні.

\section{ЛІТЕРАТУРА}

1. Булгакова В. Адаптувати людину до життя. Іноземні мови в навчальних закладах. 2005. №6. С.82-86.

2. Зеер Э.Ф. Психология профессионального образования. Москва, Воронеж, 2003. 480 с.

3. Зимняя И.А. Психологические аспекты обучения говорению на иностранном языке. Москва, 1978 с. $159 \mathrm{c}$.

4. Китайгородская И.А. Методика интенсивного обучения иностранным языкам. Москва, 1986. 100 с.

5. Леонтьев А.Н. Деятельность. Сознание. Личность. Москва, $1975.304 \mathrm{c.}$

6. Лобачук I.М. Комунікативна компетентність викладача іноземної мови як важлива складова педагогічної майстерності. Наукові записки
Вінницького державного педагогічного університету імені Михайла Коиюбинського. Серія: Педагогіка і психологія: зб. наук. праць / редкол.: В.І.Шахов (голова) та ін. Вінниця, 2018. Вип. 53. С.133137.

7. Малінка О.О. Педагогічні умови розвитку мотивації до вивчення іноземних мов у студентів освітніх закладів культури : дис. ... канд. пед. наук: 13.00.04 / НПУ ім. М.П.Драгоманова. Київ, 2010. 212 с.

8. Маслова Ю.В. Содержание и формы иноязычной речевой деятельности студентов пед. вуза в контекстном обучении (на материале английского языка) : автореф. дис. ...канд.пед.наук : 13.00.08. Липецк, 2000. 26 с.

9. Пассов Е.И. Коммуникативный метод обучения иноязычному говорению. Москва, 1991. 223 с.

10. Пометун О.I. Запровадження компетентнісного підходу - перспективний напрямок розвитку сучасної освіти. Вісник. 2004. № 22. URL: http:www.Visnyk@iatr.org.ua (дата звернення: 31.01.2019)

11. Сорочан Т. Характеристика професіоналізму управлінської діяльності керівників шкіл на засадах компетентнісного підходу. Шлях освіти. 2005. №3. С.912.

\section{REFERENCES}

1. Bulgakova, V. (2005). Adaptuvaty lyudynu do zhyttya [To adapt a person to life]. Foreign languages at educational institutions. No.6. pp.82-86. [in Ukrainian].

2. Zeyer, E.F. (2003). Psikhologiya professionalnogo obrazovaniya [Psychology of professional education]. Moscow, Voronezh, 480 p. [in Russian].

3. Zimnyaia, I. A. (1978). Psikhologicheskie aspekty obuchenia govoreniyu na inostrannom yazyke [Psychological aspects of teaching foreign language speaking]. Moscow, 159 p. [in Russian].

4. Kitaigorodskaya, I.A. (1986). Metodika intensivnogo obuchenia inostrannym yazykam [Methods of intensive foreign languages teaching]. Moscow, $100 \mathrm{p}$. [in Russian].

5. Leontyev, A.N. (1975). Deyatelnost. Soznanie. Lichnost [Activity.Consciousness. Personality]. Moscow, 304 p. [in Russian].

6. Lobachuk, I.M. (2018). Komunikatyvna kompetentnist vykladacha inozemnoii movy yak vazhlyva skladova pedagogichnoii maisternosti [Communcative competence of a foreign language teacher as an important component of pedagogical proficiency]. Scientific Notes of Vinnytsia State Pedagogical University named after Mykhailo Kotsiubynskyi. Series: pedagogics and psychology. Vinnytsia. Vol. 53. pp.133-137. [in Ukrainian].

7. Malinka, O.O.(2010). Pedagogichni umovy rozvytku motyvatsii do vyvchennya inozemnykh mov u studentiv osvitnikh zakladiv kultury [Pedagogical conditions of developing foreign languages learning motivation of students of educational institutions of the sphere of culture]. Candidate's thesis. Kyiv, 212 p. [in Ukrainian].

8. Maslova, Yu.V. (2000). Soderzhanie i formy inoyazychnoi rechevoi deyatel'nosti studentov ped. vuza $\mathrm{v}$ kontekstnom obuchenii (na materiale angliiskogo yazyka) [Content and forms of foreign language speaking activity of students of a pedagogical university in 


\section{РОЗВИТОК АВТОНОМНОСТІСТУДЕНТІВ ЗАКЛАДІВ ВИЩОЇ ОСВІТИ: ВАЛЕНТНО-ФРАКТАЛЬНИЙ ВИМІР РОЗУМІННЯПРОБЛЕМИ}

contextual teaching (on the material of the English language)]. Extended abstract of candidate's thesis. Lipetsk, 26 p. [in Russian].

9. Passov, Ye.I. (1991). Kommunikativnyi metod obucheniya inoyazychnomu govoreniyu [Communicative method of teaching foreign language speaking]. Moscow, 223 p. [in Russian].

10. Pometun, O.I. (2004). Zaprovadzhennya kompetentnisnogo pidkhodu - perspektyvnyi napryamok rozvytku suchasnoii osvity [Implementation of competency-based approach - a promising direction of modern education development]. Journal. 22. Available at: http:www.Visnyk@iatr.org.ua (Accessed 31 Jan. 2019) [in Ukrainian].

11. Sorochan, T. (2005). Kharakterystyka professionalismu upravlinskoi diyalnosti kerivnykiv shkil na zasadakh kompetentnisnogo pidkhodu [Characteristics of professionalism of managerial activity of head masters within the framework of competency-based approach]. The Way of Education. No.3. pp.9-12. [in Ukrainian].

Стаття надійшла до редакції 19.03.2019

УДК 37.091 .313

DOI:

Роман Попов, кандидат наук з державного управління, дочент кафедри романо-германських мов і перекладу, Національний університет біоресурсів і природокористування Украӥни

\section{РОЗВИТОК АВТОНОМНОСТІ СТУДЕНТІВ ЗАКЛАДІВ ВИЩОЇ ОСВІТИ: ВАЛЕНТНО-ФРАКТАЛЬНИЙ ВИМІР РОЗУМІННЯ ПРОБЛЕМИ}

У статті представлено структуру автономності студентів закладів вищої освіти як певне об 'єднання фракталів, щзо сполучають складники та елементи складників. У структурі автономності студента існують декілька фракталів, кожен фрактал утворюється ітерачійно (иляхом ітерації - шляхом повторного застосування), за певними векторами. Кожен із складників має свою вагу, иінність, якуназивають валентністю.

Ключові слова: автономність студентів; структура автономності студентів; фрактал; валентність. Jim. 15.

Roman Popov, Ph.D.(Public Administration), Assistant Professor of the Romance and Germanic Languages and Translation Department, National University of Life and Environmental Sciences of Ukraine

\section{DEVELOPMENT OF HIGHER EDUCATION INSTITUTIONS STUDENTS'AUTONOMY: VALENCES-FRACTAL MEASURES OF DEFENSE OF PROBLEMS}

Building the Ukrainian state sets to the agenda a very important and urgent task - to form during the period of professional training a real citizen-professional, a democrat, a person with independent outlook and convictions. Sharing the ideas of the national and Western European pedagogues, we define education as the fundamental category of the pedagogical science. We are of the opinion that the most favorable background for the formation of autonomy is created through the integration of students' educational and self-educational activities at higher educational institutions. The integration of the educational and self-educational activities creates a favorable background for the development of the autonomy of higher educational institutions students. An area where these kinds of activities meet and at the same time the area of students' autonomy development is the extracurricular educational activity, individual activity which is conducted without any control from the lecturers and can either correspond to the content, curriculum and professional training program, or supplement them. At the same time, students'autonomy is not a synonym to the autonomous activity, since it in its structure it has (we will mention that later) not only pro-active, but also professionally-personal traits and components. Due to the integration of the educational and self-educational activities arises a certain state of a subject's psychological readiness for autonomous activity and we define this kind of readiness as an integral characteristic of a personality, reflecting the development level and the qualitative specifics of the structure of educational activities.

We imagine the structure of autonomy as a certain amalgamation of fractals which join the components and elements of the components. Weproceed from the premise that within the structure of students' autonomy there are several fractals, andeach one of them forms iteratively (by means of iteration - through repetitious application), according to certain vectors. Each component has its own weight, value, which we call the valence. The generalization of the psychologically-pedagogical information allows marking the following valences in the structure of each fractal: gnoseological, axiological, praxeological. The content and sense of each fractal of the autonomy can be analyzed and rated from the gnoseological, emotionally-axiological and praxeological perspectives.

Keywords: autonomy of students; a structure of autonomy of students; fractal; valency.

П

остановка проблеми. Розбудова української держави висуває на порядок денний надзвичайно важливе і невідкладне завдання - формування за період отримання професійної підготовки справжнього громадянина-професіонала, демократа, людини 3 